\title{
A Giant Pituitary Adenoma in a Patient under Salmon Calcitonin Treatment: Coincidence or a Priori Consequence M Kara ${ }^{1}$, Ö Kara ${ }^{2}$, L Ozçakar ${ }^{1}$
}

The Editor, Sir,

A 57-year-old woman with hypertension had been diagnosed as postmenopausal osteoporosis (OP), and nasal salmon calcitonin treatment had been started In June 1997. In October 1997, she had been admitted for headache and hypertension. Cranial tomography -performed for hypertension- had been normal, and she had been successfully treated with antihypertensive therapy. She had been regularly followed during salmon calcitonin therapy until 2002.

In November 2002, the patient presented with headache, ptosis, diplopia and loss of vision. Magnetic resonance imaging demonstrated a heterogeneous lesion $(4.1 \times 3.6 \times 3.7 \mathrm{~cm})$ invading sphenoid/cavernous sinuses, eroding clivus and pituitary stalk, and compressing the optic chiasm (Fig. 1). Laboratory analysis for hormones was normal (Table-1). Overall, the patient was diagnosed as a non-functioning pituitary macroadenoma. First, she underwent transsphenoidal adenoma excision and one month later, right pteroidal craniotomy. As TSH and GH levels decreased postoperatively (Table-1), thyroid replacement therapy, and alendronate (instead of calcitonin) was prescribed. Postoperative course was otherwise uneventful with partial improvement in the oculomotor palsy and the residual macroadenoma was stabilized $(2.5 \times 2.5 \times 1.5 \mathrm{~cm})$. One year later, gamma knife surgery was also performed. Up to now, she has been followed regularly without any additional neurologic/hormonal dysfunction.

Pituitary adenomas are rare benign tumors, classified according to the size as microadenomas $<1 \mathrm{~cm}$ or macroadenomas $>1 \mathrm{~cm}$; or according to hormonal hypersecretion as functional or nonfunctional. ${ }^{1}$ Pituitary macroadenomas often cause neurological symptoms 
due to mass effects such as visual field disturbances and headache. ${ }^{2}$ Surgery is the first-line treatment, and gamma knife radiosurgery and radiotherapy are effective for residual tumors.

Calcitonin is mainly synthesized by C-cells of the thyroid gland and also secreted in several other neuroendocrine organs such as brain, lungs, and pituitary gland. ${ }^{3}$ On the other hand, calcitonin receptors are mainly found on osteoclasts and at certain sites in the nervous system including hypothalamus, circumventricular organs, preoptic nucleus and anterior pituitary. ${ }^{4}$ Calcitonin inhibits osteoclastic activity leading to reduced bone resorption. Salmon calcitonin, a more potent form than human calcitonin, has been used for the treatment of OP without any major adverse effects. However, salmon calcitonin administration for one year was found to be associated with pituitary gland hyperplasia/adenoma in rats. ${ }^{5,6}$ Although we were not able to exclude a sporadic pituitary microadenoma in our patient before the calcitonin treatment and we did not have any detailed histological/biochemical analysis of the surgical specimens demonstrating the expression of the calcitonin receptor; we propose that calcitonin might have induced/accelerated the development of an adenoma.

Presenting the first case in the literature, we imply that screening studies are definitely awaited before we can conclude that our observation does not fall beyond a coincidence. Additionally, clinicians prescribing calcitonin should consider such a possibility and be vigilant against hormonal/neurological consequences due to aforementioned mechanisms.

Keywords: Calcitonin, diplopia, osteoporosis, pituitary adenoma

From: ${ }^{1}$ Department of Physical and Rehabilitation Medicine, Hacettepe University Medical School, Ankara, Turkey and ${ }^{2}$ Department of Internal Medicine, Division of Geriatrics, Gazi University Medical School, Ankara, Turkey.

Correspondence: Dr M Kara, Tıp Fakültesi Hastaneleri, Hacettepe Üniversitesi, Zemin Kat FTR AD, Ankara, Turkey. Fax: +90 312 3105769; e-mail: mkaraftr@yahoo.com. 


\section{REFERENCES}

1. Ezzat S, Asa SL, Couldwell WT, Barr CE, Dodge WE, Vance ML, et al. The Prevalence of pituitary adenomas. Cancer 2004; 101: 613-9.

2. Colao A, Di Somma C, Pivonello R, Faggiano A, Lombardi G, Savastano S. Medical therapy for clinically non-functioning pituitary adenomas. Endocr Relat Cancer 2008; 15: $905-15$.

3. Sun YP, Lee TJ, Shah GV. Calcitonin expression in rat anterior pituitary gland is regulated by ovarian steroid hormones. Endocrinology 2002; 143: 4056-64.

4. Vik A, Yatham LN. Calcitonin and bipolar disorder: a hypothesis revisited. J Psychiatry Neurosci 1998; 23: 109-17.

5. Brown WR, Fetter AD, Van Ryzin RJ, Langloss JM. Proliferative pituitary lesions in rats treated with salmon or porcine calcitonin. Toxicol Pathol 1993; 21: 81-6.

6. Ishii J, Katayama S, Itabashi A, Takahama M, Kawazu S. Salmon calcitonin induces pituitary tumor in rats. Endocrinol Jpn 1991; 38: 705-9. 
Table 1: Serum pituitary hormone levels of the patient in different times.

\begin{tabular}{lccc}
\hline & Before surgery & After surgery & Current \\
TSH $(0.27-4.2 \mu \mathrm{IU} / \mathrm{ml})$ & 2.11 & $\mathbf{0 . 1 1}$ & 2.48 \\
GH $(1-9 \mathrm{ng} / \mathrm{ml})$ & 2.6 & $\mathbf{0 . 1 9}$ & 1.1 \\
ACTH $(9-52 \mathrm{pg} / \mathrm{ml})$ & 10.5 & 25.3 & 30.5 \\
PRL $(1.9-25 \mathrm{ng} / \mathrm{ml})$ & 14.5 & 7.39 & 9.2 \\
FSH $(25.8-134.8 \mu \mathrm{IU} / \mathrm{ml})$ & 33.56 & 39.02 & 36.1 \\
LH $(7.7-58.5 \mu \mathrm{IU} / \mathrm{ml})$ & 12.53 & 12.26 & 14.1 \\
\end{tabular}

TSH, thyroid-stimulating hormone; GH, growth hormone

ACTH, adrenocorticotropic hormone; PRL, prolactin; FSH, follicle-stimulating hormone LH, luteinizing hormone 


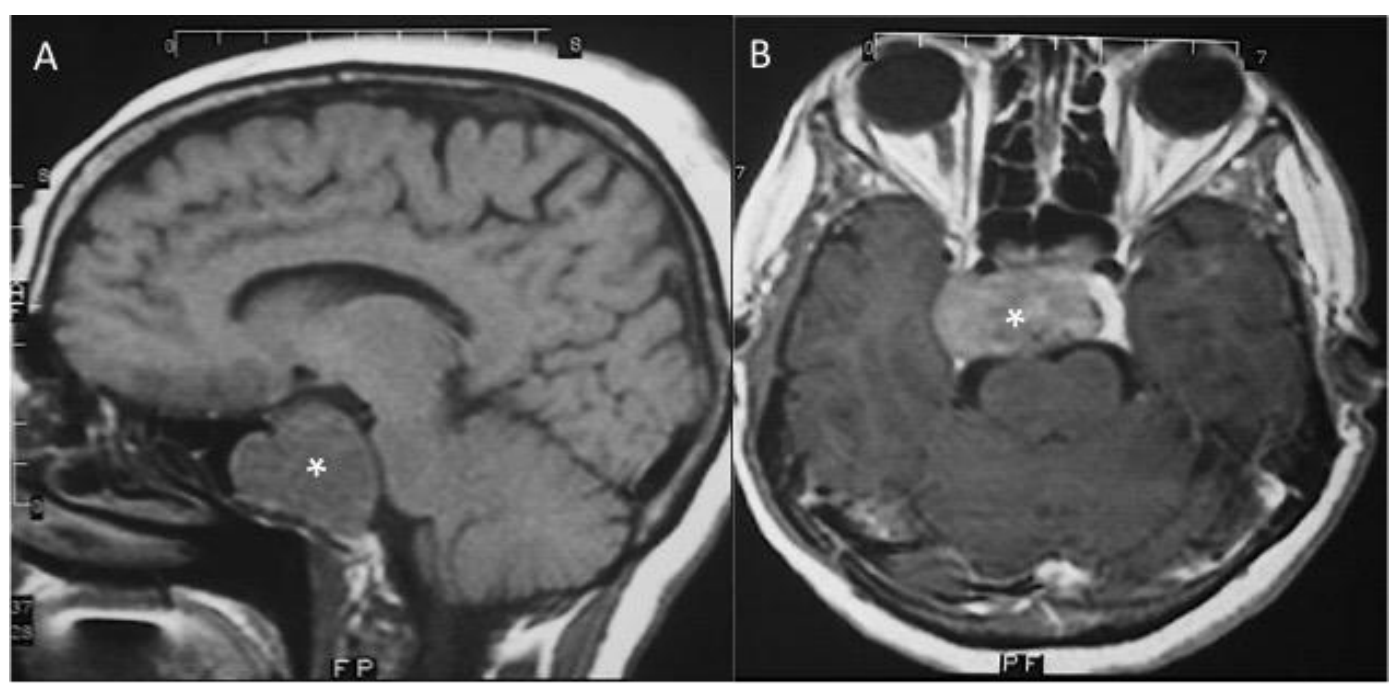

Figure 1: T1-weighted magnetic resonance imaging a) sagittal view, b) axial view (with gadolinium-enhancement) showing the pituitary macroadenoma with massive suprasellar extension and invasion to the sphenoid and cavernous sinuses mainly on the right side. 